\title{
Peertechz
}

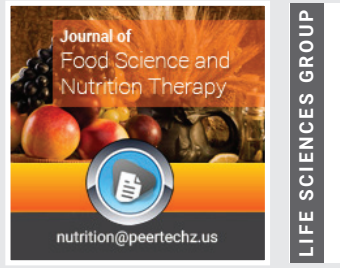

\section{Biochemical applications and application of indicators in blood and lymph after a new feed additive based on bentonite}

\section{Demchenko GA ${ }^{1 *}$, Makashev EK², Bachtiyarova ShK³, Abdreshov $\mathrm{SN}^{4}$ and Koibasova $\mathrm{LU}^{5}$}

${ }^{1}$ Head of Laboratory of the Lymph System Physiology, Institute of Genetics and Physiology CS MES RK, Almaty, Kazakhstan

2Doctor of Biological Sciences, Corresponding Member of the National Academy of Sciences RK, Institute of Genetics and Physiology CS MES RK, Almaty, Kazakhstan

${ }^{3} \mathrm{~A}$ Candidate of Biological Sciences, heard of Laboratory of Ecological Physiology Institute of Genetics and Physiology CS MES RK, Almaty, Kazakhstan

${ }^{4}$ Candidate's Degree in Biological Sciences, Assistant Professor Laboratory of the Lymph System Physiology, Institute of Genetics and Physiology CS MES RK, Almaty, Kazakhstan

${ }^{5}$ Candidate of Biological Sciences, Deputy Director for Science of the Institute of Genetics and Physiology CS MES RK, Almaty, Kazakhstan
Received: 24 December, 2021

Accepted: 01 February, 2022

Published: 02 February, 2022

*Corresponding author: Demchenko GA, Head of Laboratory of the Lymph System Physiology, Institute of Genetics and Physiology CS MES RK, Almaty, Kazakhstan, E-mail: georgiidemchenko@mail.ru

ORCID: https://orcid.org/0000-0001-9906-2700 Keywords: Feed additive; Nutrition of agricultural animals; Biochemistry of blood and lymph

Copyright Licence: (C) 2022 Demchenko GA, et al. This is an open-access article distributed under the terms of the Creative Commons Attribution License, which permits unrestricted use, distribution, and reproduction in any medium, provided the original author and source are credited.

https://www.peertechzpublications.com

\section{Check for updates}

\section{Abstract}

The aim of the study was to assess the physiological and biochemical action the new feed additive.

The studies were carried out on white laboratory rats of the Spraque Dawley line. The additive consisted of four ingredients - bentonite, barley, wheat, calcium phosphate, in the ratio (2: 8: 8: 2). The use of fortified, enriched with vegetable fat-protein components, feed additive with natural montmorillonite (bentonite) affects the protein, carbohydrate and fat metabolism in the body, contributes to an increase in the weight of the animal. After prolonged intake of the feed additive, enzymatic activity and an increase in the content of protein, glucose, and lipids in the blood were observed. The feed additive has a good adsorptive and antioxidant effect, reducing toxic products, participating in the inactivation of free radicals, and exerting a protective effect on cell membranes. When feeding with a fodder additive, the protein content in the diet increased, as compared with the control, it should be noted that the phosphorus content in the blood and lymph increased, the increase in energy costs increased with an increase in muscle mass. The supplement is high in calories, has an antioxidant and adaptogenic effect, maintains a balance of biochemical and oxidative processes and can be recommended as a safe and effective supplement to the daily diet of farm animals.

To increase the productivity of farm animals, new feed additives are being developed and introduced that improve the processes of digestion and absorption, ensuring the safety and quality of products [1]. The composition of the Feed Additive (FA) must comply with the regulatory data for any diet when feeding farm animals. In order to ensure the safety of meat and dairy products, the use of montmorillonites is becoming increasingly popular, since clayey layered minerals have a number of properties, such as sorption, complexing, biocompatibility, which allows them to be widely used as components of feed additives that meet the basic principles of "green" chemistry [2]. Tagansorbent, bentonite, zeolites, silica gel, activated carbon, shungite, mined in Kazakhstan, are able to stop various intoxications, adsorb harmful substances in the food supply of farm animals [3]. It should be noted that many montmorillonites exhibit high complexing activity with ions of various elements, which reduces the level of toxic substances in the cells and tissues of the body and improves its blood 
supply [4]. The main montmorillonites, tagansorbents and zeolites, are not absorbed into the blood, but adsorb all harmful substances in the blood, carrying out a general detoxification of the body, which improves the quality and nutritional value of agricultural products [5]. For enhanced growth of young animals, vitamins and microelements, such as calcium, zinc, iodine, fluorine, potassium, sodium, and phosphorus are also needed $[6,7]$. For example, the normal content of vitamin A is responsible for the normal functioning of the digestive system, prevents miscarriages, improves reproductive function, stimulates the growth of young animals, and prevents obesity [8]. Like iodine, zinc maintains stable milk yield, reproductive function, which is responsible for the normal functioning of the thyroid gland [9]. Potassium, sodium regulates the watersalt balance, prevent the occurrence of anemia [10] in case of dysfunction of the cardiovascular system. The use of various fortified feed additives based on montmorillonite components improves the functional activity of digestive processes, stimulates the growth and development of young animals, and affects the quality of meat and dairy products. Studies of blood and lymph circulation, as the internal environment of any organism, anatomically and functionally interconnected with the digestive system of animals, are necessary to identify water-salt, biochemical and enzymatic processes that occur in the body after the use of various feeds or feed additives, which is necessary to obtain high-quality products.

The aim of the study was to evaluate the physiological and biochemical effects of a new feed additive on linear rats with subsequent use on farm animals.

\section{Materials and research methods}

The studies were carried out on 55 white laboratory rats of the Sprague-Dawley (SD) line, weighing $277 \pm 17$ grams, divided into 2 groups - the control group (25) - were on the main food of the vivarium and the experimental group of animals (30) took FA in granules for 21 days. The additive consisted of four ingredients - bentonite, barley, wheat, calcium phosphate, in the ratio (2: 8: 8: 2). The composition of bentonite also includes, \%: $\mathrm{SiO} 2$-57.84; Al2O3-14.29; Fe2O3-5.93; FeO-1.14; $\mathrm{CaO}-0.99 ; \mathrm{MgO}-2.79 ; \mathrm{K} 2 \mathrm{O}-2.10 ; \mathrm{Na} 2 \mathrm{O}-1.15 ; \mathrm{SO} 3-0.62$. The content of radionuclides in bentonite samples does not exceed the permissible limits. The bentonite deposit is located in the Saryagach district of the Chimkent region of the Republic of Kazakhstan.

Anesthesia of animals was carried out by inhalation with ether through a mask, into which with ether was placed. After anesthesia, an incision was made along the white line of the abdominal muscles, then the thoracic lymphatic duct was dissected at the diaphragm into which a graduated microcannula was inserted, and through it, the lymph flow was determined and the lymph was collected for research. After collecting lymph, the abdominal aorta was dissected in the caudal part of the abdominal cavity, and a Teflon catheter was inserted into it to collect blood. Diuresis from the urinary bladder BP and heart rate were recorded by the sensors of the Dreiger surgical monitor.
The cellular composition of blood, lymph, urine was determined using a hematological analyzer (SYSMEX KX-219). Electrolytes in lymph and blood plasma were analyzed using an AVL9190 analyzer (ROSHE DIAGNOSTICS, Austria, 2012). Blood pressure, heart rate (HR) in animals were recorded through a sensor of a surgical monitor (DREGOR, modelGAMMA). Biochemical studies of blood and lymph included determination of the level of total protein, albumin, triglycerides, cholesterol, glucose, bilirubin, ALT and AST enzymes, alkaline phosphatase, trace elements phosphorus and magnesium on a biochemical analyzer A-25 BIOSYSTEMS (Spain) using test kits according to the standard methodology. The state of oxidative activity in the blood was determined by the level of malondialdehyde, diene conjugates, and the level of catalase. The results obtained were statistically processed using the Microsoft Excel program and changing the parameters taking into account the unpaired Fisher-Student test and were considered reliable at $\mathrm{p} \leq 0.05$.

In studies on laboratory animals, we were guided by the decision of the LEK - an extract from the protocol of the Local Ethical Commission at the Republican State Enterprise "Institute of Human and Animal Physiology" (IFCJ) KN MES RK No. 3 (3) dated 10/08/2020 ref. No. 07-05 / 158.

\section{Research results}

After 21 days of feeding the animals, the FD weight increased by $6.6 \%(269 \pm 17$ and $288 \pm 21)$, in the control group by $2.1 \%(277 \pm 17$ and $281 \pm 19)$.

Lymphatic flow in control rats was $0.0031 \pm 0.0002 \mathrm{ml} / \mathrm{min}$. per $100 \mathrm{~g}$ of animal weight, and after feeding, FD, corresponding to $0.0056 \pm 0.0005 \mathrm{ml} / \mathrm{min}$. The blood coagulability in the control animals was within $3.09 \pm 0.5 \mathrm{~min}$, and after feeding, the FD corresponded to $3.48 \pm 0.4 \mathrm{~min}$. In the lymph of the control animals, $3.1 \pm 0.5$ minutes, and after feeding, the FD was $3.68 \pm 0.4$ minutes. The blood viscosity in the control groups was $4.5 \pm 0.5 \mathrm{P}$ units, and after feeding, FD was $5.3 \pm 0.4 \mathrm{P}$ units. In the lymph of the control group, the animals corresponded to $3.9 \pm 0.5$ units, and after feeding, the FD was $4.1 \pm 0.6 \mathrm{P}$. The volume of plasma by hematacrit in the control was $45.0 \pm 3.2 \%$ and in the experimental $48.0 \pm 4.0 \%$. Heart rate in control animals is $481 \pm 11$ beats per minute. Blood pressure in control animals corresponded to $103 \pm 7$ and in experimental animals $105 \pm 9$. Diuresis in control animals is $0.0018 \pm 0.0001 \mathrm{ml} / \mathrm{min}$. per $100 \mathrm{~g}$ of body weight, and after feeding, FD $0.0029 \pm 0.0001 \mathrm{ml} /$ min per $100 \mathrm{~g}$.

Studies of the cellular composition of the blood and lymph of experimental animals showed that the level of leukocytes, lymphocytes and erythrocytes fluctuated at the level of control values, there was a decrease in platelet concentration and an increase in hemoglobin after application of FD (Table 1).

After the application of FD in the blood serum, the level of Alb and OB increased by $11 \%$, the protein level in the lymph was maintained in comparison with the control, and the glucose level, both in the blood and in the lymph, increased 1.5 times. The concentration of High-Density Cholesterol (HDL) in blood plasma increased by $30 \%$ compared to the control, and in the 
lymph by $28 \%$, and LDL with low density increased by $28 \%$, in the control group by $13 \%$. Biochemical parameters of lymph in terms of proteins and lipids corresponded to those of blood plasma. Consequently, the use of FD showed an increase in the level of total protein due to albumin, as well as an increase in the concentration of glucose, triglycerides and cholesterol, especially with a low density. Elevated high-density HDL cholesterol levels indicate increased metabolic processes in the liver and utilization of excess cholesterol Table 2.

An increase in the activity of such enzymes as (ALT), (AST), (ALP) in blood plasma and lymph to a greater extent reflects the state of permeability of cell membranes, liver and myocardium.

When comparing the control data with the indicators of the experimental group taking FD, an increase in the ALT level by $44 \%$ in the blood was revealed, in the AST level by $59 \%$, and an increase in the ALP level by $59 \%$, the bilirubin level increased by $46 \%$, the level of creatinine by $26 \%$, urea by $55 \%$.

In the lymph, almost all indicators of enzymatic activity, as well as the level of pigment bilirubin and creatinine, showed an increase of $20-50 \%$. It is likely that the increase in bilirubin

Table 1: Cellular composition of blood and lymph of animals taking FD. Compared with the data of the control group.

\begin{tabular}{c|c|c|c|c|}
\hline Indicators & \multicolumn{2}{|c|}{ Blood } & \multicolumn{2}{|c|}{ Lymph } \\
\hline $\mathrm{WBC} \times 10^{3} / \mu \mathrm{L}$ & $7.50 \pm 0.10$ & $6.90 \pm 0.20^{\star}$ & $15.2 \pm 0.32$ & $14.9 \pm 0.51$ \\
\hline $\mathrm{RBC} \times 10^{6} / \mu \mathrm{L}$ & $7.40 \pm 0.20$ & $7.73 \pm 0.45$ & $0.02 \pm 0.003$ & $0.01 \pm 0.002^{\star}$ \\
\hline $\mathrm{HGB} \mathrm{g} / \mathrm{dL}$ & $15.0 \pm 0.30$ & $14.88 \pm 0.43$ & - & - \\
\hline Hct\% гематокрит & $45.0 \pm 3.20$ & $48.04 \pm 4.01$ & - & - \\
\hline $\mathrm{PLTx} 10^{3} / \mu \mathrm{L}$ & $425.0 \pm 14.0$ & $395.0 \pm 19.2$ & & - \\
\hline $\mathrm{LYM} \%$ & $55.50 \pm 3.40$ & $54.25 \pm 3.82$ & $85.0 \pm 0.85$ & $88.0 \pm 0.91$ \\
\hline $\mathrm{LYM} \times 10^{3} / \mu \mathrm{L}$ & $2.70 \pm 0.31$ & $2.70 \pm 0.52$ & $13.0 \pm 0.41$ & $12.6 \pm 0.42$ \\
\hline
\end{tabular}

Note: reliable compared to control. $-\mathrm{p}<0.05^{\star}$

Table 2: Biochemical parameters of blood plasma and lymph after application of FD.

\begin{tabular}{|c|c|c|c|c|}
\hline \multirow{2}{*}{ Indicators } & \multicolumn{2}{|c|}{ Blood plasma } & \multicolumn{2}{|c|}{ Lymph } \\
\hline & control & FA & control & FA \\
\hline Albumin. g/l & $23.90 \pm 1.6$ & $26.72 \pm 1.8$ & $10.10 \pm 0.7$ & $11.09 \pm 0.9$ \\
\hline Total protein $\mathrm{g} / \mathrm{l}$ & $63.41 \pm 10.1$ & $71.40 \pm 10.0$ & $39.32 \pm 4.0$ & $39.52 \pm 6.1$ \\
\hline Glucose. mmol/l & $12.55 \pm 1.1$ & $19.29 \pm 1.5^{\star}$ & $9.35 \pm 0.7$ & $13.92 \pm 0.8^{*}$ \\
\hline HDL cholesterol mmol/l & $0.48 \pm 0.03$ & $0.62 \pm 0.01^{*}$ & $0.39 \pm 0.02$ & $0.50 \pm 0.03^{\star}$ \\
\hline LDL cholesterol mmol/l & $0.39 \pm 0.01$ & $0.50 \pm 0.01 *$ & $0.37 \pm 0.04$ & $0.42 \pm 0.06$ \\
\hline ALAT. units/I & $154.70 \pm 17.0$ & $223.01 \pm 16.6^{*}$ & $150.01 \pm 10.8$ & $141.3 \pm 3.4$ \\
\hline AsAT. u/l & $118.40 \pm 9.3$ & $188.73 \pm 10.4^{*}$ & $80.02 \pm 11.5$ & $92.92 \pm 7.1^{*}$ \\
\hline Bilirubin. $\mu \mathrm{mol} / \mathrm{I}$ & $15.30 \pm 0.7$ & $22.43 \pm 0.9 *$ & $1.50 \pm 0.04$ & $2.32 \pm 0.05^{\star}$ \\
\hline Creatinine. $\mu \mathrm{mol} / \mathrm{l}$ & $45.10 \pm 0.22$ & $56.82 \pm 0.15^{\star}$ & $42.43 \pm 3.8$ & $69.32 \pm 4.3^{\star}$ \\
\hline Triglycerides.mmol/l & $0.84 \pm 0.03$ & $0.93 \pm 0.01 *$ & $3.72 \pm 0.5$ & $4.12 \pm 0.7$ \\
\hline $\begin{array}{l}\text { Alkaline phosphatase. } \\
\text { U/I }\end{array}$ & $264.20 \pm 10.4$ & $305.01 \pm 12.2^{*}$ & $180.23 \pm 14.0$ & $217.23 \pm 19.0$ * \\
\hline Urea. mmol/l & $3.00 \pm 0.5$ & $5.58 \pm 0.5^{\star}$ & $3.90 \pm 0.20$ & $5.00 \pm 0.16$ \\
\hline
\end{tabular}

Note: reliable compared to control.-p $<0.05^{\star}$ and creatinine is associated with a saturated protein diet and an increase in the body weight of animals when fed with FD.

In general, the analysis of biochemical data in the blood and lymph showed that after feeding with FD, a general tendency was observed - an increase in the concentration of indicators of protein, fat and carbohydrate metabolism in the blood of animals, namely, an increase in the concentration of total protein, albumin and glucose, as well as cholesterol, enzymatic activity, which indicates a high level of protein-carbohydratefat supply of the body when feeding FD. It should be noted that after the use of FD, the level of triglycerides increased by $12 \%$, the concentration of low-density cholesterol and bilirubin, ALT and AST increased by 2 times, which indicates an increase in the activity of lipid metabolism and the regulatory role of the liver with an increase in the live body weight of animals.

The results of studies of ions of trace elements in blood plasma, lymph and urine of animals are presented in Table 3.

As shown in Table 3, the level of $\mathrm{Na}+$ ions in the blood and lymph during feeding with FD was slightly higher than the control values $(2 \%)$, but $\mathrm{Na}+$ was washed out with urine after taking FD by $8.5 \%$ higher than in the control data. It is likely that the components of FD bind sodium ions due to bentonite and excrete them with urine, that is, they have a diuretic effect.

After taking FD, the level of both magnesium and phosphorus increased by $28 \%$ and $35 \%$, respectively.

Lipid Peroxidation (LPO) is a vital link in metabolic metabolism. The results of studies of lipid peroxidation in the blood of animals taking FD are presented in Table 4 .

After the application of FD, the level of catalase activity was $25 \%$ lower than the control values, which characterizes the degree of inhibition of metabolic processes on the membranes and an increase in the processes of hepatic dysfunction. At the same time, the concentration of diene conjugates (DCs) of fatty acid hydroperoxides was $7 \%$ less than the control values, MDA as a final product - by $2 \%$, that is, after the application of FD activation of LPO processes is not observed, but inhibition of antioxidant activity is observed (Table 4).

\section{Discussion}

The study showed that FD components enhanced the drainage and transport functions of the lymphatic system. FD did not affect cardiac activity - the heart rate of the animals fluctuated within the control values. Changes in the diuresis of animals showed a 1.5-2.0 -fold increase after the application of $\mathrm{FD}$, which is a consequence of a slight increase in the liquid part of blood and lymph in the vessels and shows an increase in tissue hydration and the activity of metabolic processes in the body, after the application of FD.

The use of natural sources of mineral substances greatly facilitates the organization of the mineral nutrition of animals, contributes to a better provision of their needs for macroand microelements, and has a positive effect on the body's homeostasis [11]. 
Table 3: Content of ions of trace elements in blood plasma. Lymph and urine of animals after application of FD.

\begin{tabular}{|c|c|c|}
\hline Electrolytes & Control & FA \\
\hline $\mathrm{Ca}^{+}$in plasma $(\mathrm{mmol} / \mathrm{l})$ & $0.58 \pm 0.03$ & $0.62 \pm 0.05$ \\
\hline $\mathrm{Na}^{+}$in plasma $(\mathrm{mmol} / \mathrm{l})$ & $140.5 \pm 5.40$ & $144 \pm 6.50$ \\
\hline $\mathrm{K}^{+}$in plasma $(\mathrm{mmol} / \mathrm{l})$ & $3.16 \pm 0.30$ & $3.08 \pm 0.50$ \\
\hline $\mathrm{Mg}^{+}$in plasma $(\mathrm{mmol} / \mathrm{l})$ & $0.39 \pm 0.01$ & $0.50 \pm 0.01$ \\
\hline $\mathrm{P}^{+}$in plasma $(\mathrm{mmol} / \mathrm{l})$ & $1.66 \pm 0.03$ & $2.16 \pm 0.04^{\star}$ \\
\hline $\mathrm{Ca}^{+}$in lymph $(\mathrm{mmol} / \mathrm{l})$ & $0.40 \pm 0.03$ & $0.45 \pm 0.04$ \\
\hline $\mathrm{Na}^{+}$in lymph $(\mathrm{mmol} / \mathrm{l})$ & $135.1 \pm 4.5$ & $139 \pm 8.50$ \\
\hline $\mathrm{K}^{+}$in lymph $(\mathrm{mmol} / \mathrm{l})$ & $3.52 \pm 0.20$ & $3.6 \pm 0.40$ \\
\hline $\mathrm{Mg}^{+}$in lymph $(\mathrm{mmol} / \mathrm{l})$ & $0.35 \pm 0.10$ & $0.45 \pm 0.01$ \\
\hline $\mathrm{P}^{+}$in lymph $(\mathrm{mmol} / \mathrm{l})$ & $1.68 \pm 0.10$ & $1.9 \pm 0.01^{*}$ \\
\hline Ca ${ }^{+}$in urine & - & - \\
\hline $\mathrm{Na}^{+}$in urine $(\mathrm{mmol} / \mathrm{l})$ & $16.41 \pm 1.02$ & $17.8 \pm 2.00$ \\
\hline $\mathrm{K}^{+}$in urine $(\mathrm{mmol} / \mathrm{l})$ & $3.14 \pm 0.10$ & $3.16 \pm 0.30$ \\
\hline
\end{tabular}

Note: reliable compared to control. $-p<0.05^{\star}$. $-p<0.01^{* *}$

Table 4: Indicators of lipid peroxidation in the blood of animals taking FD.

\begin{tabular}{|c|c|c|c|c|}
\hline \multirow{2}{*}{$\begin{array}{c}\text { No } \\
\mathbf{n} / \mathbf{n}\end{array}$} & \multirow{2}{*}{ Group } & \multicolumn{3}{|c|}{ Indicator } \\
\cline { 3 - 5 } & & $\mathbf{D C} \mathbf{~ n m o l} / \mathbf{l}$ & $\mathrm{MDA} \mathbf{~ n m o l} / \mathbf{I}$ & $\mathbf{A K g H}_{\mathbf{2}} \mathbf{O}_{\mathbf{2}} / \mathbf{~ m l}$ \\
\hline 1 & Control $(\mathrm{n}=15)$ & $2.44 \pm 0.03$ & $0.131 \pm 0.01$ & $1.99 \pm 0.03$ \\
\hline 2 & FA $(\mathrm{n}=25)$ & $2.27 \pm 0.02$ & $0.128 \pm 0.01$ & $1.50 \pm 0.02 *$ \\
\hline
\end{tabular}

Note: $*_{-} P \leq 0.001$ compared to the control data.

The use of FD has shown the advantages of its use glucose and its protein saturation against the background of a low level of low-density cholesterol and an increase in high-density cholesterol utilized in the liver. Triglycerides show mainly the activity of protein-carbohydrate metabolism, which contributes to the growth of muscle mass without affecting hepatocytes. The revealed changes in the biochemical activity in the blood serum and lymph of the experimental animals taking FD are closer to the control data and physiological norm, while the indices of the enzymes ALT, AST, bilirubin in the group of animals taking FD were higher than the norm, which shows a tendency to develop deviations in the work of the hepatobiliary system, such as fatty liver - hepatosis, increased cytolytic activity [12].

Compound feed with carbohydrate-vitamin-mineral feed concentrate "Felutsen" K-6 contributed to an increase in the digestibility of nutrients in the diets of bulls, the growth rate of bulls by $16.13 \%$ with more rational use of feed and labor per unit of production [13].

Since the composition of feed additives includes such important trace elements as magnesium and phosphorus, studies were carried out for the presence of these substances in the blood of animals. Magnesium with calcium are responsible for the state of the skeletal system, magnesium with phosphorus regulate muscle activity and participate in the formation of vitamins B6, D and E. Deficiency of magnesium and phosphorus electrolytes leads to disruption and reduction of carbohydrate-fat metabolism of non-enzymatic components of the antioxidant defense system and the formation of oxidative stress [14]. It has been established that the use of non- traditional additives of khongurin zeolite and Kempendyai salt in the composition of feed rations contributed to an increase in milk productivity, and also improved the metabolism and physiological parameters of cattle [15].

Enzymatic oxidation serves to renew the phospholipid bilayer of cell membranes, participates in the formation of biologically active substances, detoxification of the body, and metabolic reactions. Non-enzymatic oxidation leads to the accumulation of peroxides, which significantly reduces the activity of the antioxidant system and destroys the body [16]. The applied FD does not provoke an increase in lipid peroxidation in the blood, which is associated with the antioxidant effect of the components used to inactivate free radicals and have a protective effect on cell membranes. The study of the oxidative activity of blood after the use of the feed additive showed a decrease in the level of diene conjugates and malonic dialdehyde, which shows the protective effect of antioxidant components at the level of cells and tissues, contributes to a significant activation of the non-enzymatic link of antioxidant protection.

It is likely that the insufficient content of retinol in the composition of FD worsened the antioxidant properties of this complex. So, as the diet of animals consisted entirely of FD. The use of our FD provoked a slight increase in low molecular weight cholesterol, as well as ALT, AST, alkaline phosphatase and bilirubin, therefore, it should be used as a feed supplement, but not completely replaced it with the main diet.

Studied according to the effect of the feed additive on physiological and biochemical parameters, it showed sufficient activity and can be recommended for widespread use as an additional feed with antioxidant and nutritional properties in the practice of animal husbandry.

\section{Conclusion}

Feed additive with natural montmorillonite (bentonite) preserves physiological parameters by influencing the protein, carbohydrate and fat metabolism in the body, contributing to weight gain. The feed additive has good hydration, enhances lymph circulation and urination, and removes toxic products. It has an antioxidant effect used to inactivate free radicals and has a protective effect on cell membranes.

Thus, the supplement is high-calorie, has an antioxidant and adaptogenic effect, maintains a balance of biochemical and oxidative processes, and can be recommended as a safe and effective supplement to the daily diet of farm animals, but after further research in real farm conditions.

\section{References}

1. Moldataeva LI (2020) Some problems and prospects for the development of the agro-industrial complex of the Republic of Kazakhstan. J International scientific review of the problems of economics, finance and management. Collection of scientific articles XVIII International correspondence scientific specialized conference. USA Boston 12-18.

2. Malysheva EV, Fomichev AV, Sosyukin AE, Lapina NV, Litvintsev BS, et al (2018) Modern ideas and prospects for the use of enterosorbents in the pre- 
vention and treatment of the adverse effects of heavy metal compounds. Bulletin of the Russian Military Medical Academy.

3. Belko AA, Velikanov VV, Petrov VV, Gromov IN., Malkov AA, et al. (2016) Enterosorbents in clinical veterinary practice / Textbook for students. Vitebsk: State Academician veterinarian.med $55 \mathrm{~s}$

4. Markowiak P, Slizewska K (2018) The role of probiotics, prebiotics and synbiotics in animal nutrition. Gut Pathog 10: 21. Link: https://bit.ly/3KZig8

5. Ponomarenko YuA, Fisinin VI, Egorov IA (2020) Compound feed, feed, feed additives, biologically active substances, diets, quality, safety. Monograph. Minsk: Belstan 764

6. Niyazbekova RK, Shansharova LS, Zharmagambetov AZh (2017) Development of recommendations for improving the regulatory framework in the field of organic production in Kazakhstan. Materials of the $4^{\text {th }}$ international. Dr.practical. conf. in 5 parts Prospects for the development of science in the modern world. Ufa: OOO Dendra 16-20.

7. Ginatullina AM (2018) Dynamics of the attractiveness of mineral raw materials of Kazakhstan for investment. J Geology and Protection of Mineral Resources. Almaty: 00 Kaz.geol.sobs 1: 43-48.

8. Modern advances in veterinary medicine and biology in agricultural production. Mater. 2nd All-Russian scientific-practical. conf. with international participation, I dedicate to the $100^{\text {th }}$ anniversary of H.V. Ayupova/Collection of works ed. Khaziakhmetov FS, Andreeva AV, Nikolaeva ON, - Ufa: Bashkir State Agrarian University.

9. Gorlov IF, Nelepov YuN, Karpenko EV, Kaidullina AA (2012) The influence of the feed additive "Tyksulfur" and the complex balancing additive "KBD iodum" on the growth rate of experimental bulls. Mater Int Dr.-practical. Conf. "Ways of intensification of production and processing of agricultural products in modern conditions. Volgograd: VSTU 14-16.

10. Yarovan NI, Ermakova LA () Influence of the level of feeding on the biochemical status of highly productive cows in the winter stall period. Mater All-Russian scientific-practical. conf. Chemical elements are the basis of life.

11. Utizhev AZ (2011) Enriched with bentonite silage in the diets of dairy cows. Zootechnics. 5: 12-14.

12. Kostin OV, Tishkina TN, Velmatova LN, Erofeev VI (2019) Effect of aminotransferase enzymes on the growth energy of gobies of different bodytypes. Materials of the $15^{\text {th }}$ international scientific-practical. conf dedicated in memory of S.A. Lapshin "Resource-saving environmentally friendly technologies for the production and processing of agricultural products. Saransk: NIMGU 63-66.

13. Saifullin RR, Minibaev VR, Khalirakhmanov ER, Mingazov DU, Frolova DV (2017) The use of the feed complex "Flutsen" in the feeding of farm animals. Journal of Agricultural Sciences. Problems of Science 44-47.

14. Ivanter EV, Korosov A (2010) Elementary biometrics: textbook. allowance/lzd 2.- Petrozavodsk: Publishing house of PetrSU 104

15. Chernogradskaya NM, Sharvadze RL, Krasnoshchekova TA, Grigoryeva Al Grigoriev MF (2018) Local non-traditional feed additives in cattle feeding in Yakutia. International Research Journal 5: 160-133.

16. Kozlov YuP (2016) Lipid peroxidation (LPO) as the basis of free-radical reactions in the cells of the body. J Almanac World Science M AR Consult LLC 2-1: 18-20.
Discover a bigger Impact and Visibility of your article publication with Peertechz Publications

\section{Highlights}

* Signatory publisher of ORCID

* Signatory Publisher of DORA (San Francisco Declaration on Research Assessment)

* Articles archived in worlds' renowned service providers such as Portico, CNKI, AGRIS, TDNet, Base (Bielefeld University Library), CrossRef, Scilit, J-Gate etc.

* Journals indexed in ICMJE, SHERPA/ROMEO, Google Scholar etc.

* OAI-PMH (Open Archives Initiative Protocol for Metadata Harvesting)

* Dedicated Editorial Board for every journal

* Accurate and rapid peer-review process

* Increased citations of published articles through promotions

- Reduced timeline for article publication

Submit your articles and experience a new surge in publication services (https://www.peertechz.com/submission).

Peertechz journals wishes everlasting success in your every endeavours.

Citation: Demchenko GA, Makashev EK, Bachtiyarova ShK, Abdreshov SN, Koibasova LU (2022) Biochemical applications and application of indicators in blood and lymph after a new feed additive based on bentonite. J Food Sci Nutr The 8(1): 001-005. DOI: https://dx.doi.org/10.17352/jfsnt.000031 